\title{
Plasmid R394 is a Cointegrate
}

\author{
By J. H. HAUMAN, ${ }^{*}$ R. W. HEDGES, ${ }^{2}$ W. F. COETZEE ${ }^{1}$ AND \\ J. N. COETZEE ${ }^{1}$ \\ ${ }^{1}$ MRC Unit for Microbial Genetics, University of Pretoria, P.O. Box 2034, Pretoria 0001, \\ Republic of South Africa \\ ${ }^{2}$ Department of Bacteriology, Royal Postgraduate Medical School, Hammersmith Hospital, \\ London W12 0HS, U.K.
}

(Received 23 February 1982; revised 4 May 1982)

Plasmids R394a and R394b which cointegrate to form R394 are described. They have molecular masses of $102 \pm 4$ and $11 \cdot 0 \pm 0 \cdot 4 \mathrm{MDal}$, belong to the $\mathrm{T}$ and $\mathrm{N}$ incompatibility groups and confer resistance to kanamycin and ampicillin, respectively. R394a is self transmissible and mobilizes R394b, which is non-self transmissible. These findings clarify anomalies in the behaviour of R394 and support suggestions based on the properties of variant phages derived from R394.

\section{INTRODUCTION}

$\mathrm{R}$ factor R394 from Proteus rettgeri (Coetzee et al., 1972) is a T group plasmid conferring kanamycin (Km) and ampicillin (Ap) resistance to host organisms. It has been used in various transduction studies involving Proteus mirabilis phage 5006M (Coetzee et al., 1973; Coetzee, 1974; Coetzee, $1975 a$; Coetzee \& Krizsanovich-Williams, 1976; Pretorius \& Coetzee, 1980) and Providence phage PL25 (Coetzee, 1975b). It was also used in chromosome mobilization experiments involving P. mirabilis (Coetzee, 1979) and Proteus morganii (Beck \& Coetzee, 1980). The $\beta$-lactamase determined by R394 has been studied (Hedges et al., 1974; Matthew \& Hedges, 1976).

Anomalous interactions of R394 with other plasmids have been observed, for example, in some experiments it appeared incompatible with $\mathrm{N}$ group plasmids R46 and R.390, but in others was not incompatible (Coetzee et al., 1972). This was interpreted in terms of 'dislodgement' and it was suspected that R394, although belonging to group T, contained N group DNA and that it was this segment that was excised under the influence of an $\mathrm{N}$ plasmid. The mechanism of dislodgement was not understood (Coetzee et al., 1972).

Molecular studies (Pretorius \& Coetzee, 1980) on the genome of $P$. mirabilis phages 5006M HFT $k$ and 5006M HFT $a k$, containing the kanamycin and ampicillin resistance markers of R394 (Coetzee, 1974; 1975a) prompted characterization of R394. It was observed that R394-carrying strains contained two plasmids, and this report deals with this finding in relation to the anomalous properties of $\mathrm{R} 394$ and the structure of the above variant phages.

\section{METHODS}

Bacteria, plasmids and phages. Escherichia coli K 12 strains: J53 (Clowes \& Hayes, 1968): J53-1 (Coetzee et al., 1972); J62 (Clowes \& Hayes, 1968); J62-1 (Coetzee et al., 1972); C600 r-m- (E. coli Genetic Stock Center); M259 $\mathrm{r}^{-} \mathrm{m}^{-}$(N. E. Murray, University of Edinburgh). Staphylococcus aureus: clinically isolated extracellular DNAase producing strain. Plasmids: R394, conferring resistance to ampicillin and kanamycin (Coetzec et al., 1972); R401, an Inc group T plasmid, conferring resistance to ampicillin and streptomycin (Coetzee et al., 1972); N3, an Inc group $\mathrm{N}$ plasmid, conferring resistance to streptomycin, spectinomycin, sulphonamides, tetracycline and mercury (Datta \& Hedges, 1971); RP4, an Inc group P plasmid, conferring resistance to ampicillin, kanamycin and tetracycline (Datta et al., 1971); R15, an Inc group $\mathrm{N}$ plasmid, conferring resistance to streptomycin, 
sulphonamides and mercury (Datta \& Hedges, 1971). Phages:phage $t$, an Inc group $T$ plasmid-dependent bacteriophage (Bradley et al., 1981); phage PR4, specific for pili coded for by plasmids of Inc groups P, N and W (Stanisich, 1974).

Isolation of plasmids. This was done from $E$. coli strains (see above) using the method of Prakash et al. (1981). Separation of plasmids and transformation. A plasmid R394 preparation ( $1 \mathrm{ml}$ containing $300 \mu \mathrm{g}$ DNA) was layered on to a $5-20 \%(\mathrm{w} / \mathrm{v})$ sucrose gradient in TE buffer $(10 \mathrm{mM}$-Tris/HCl $\mathrm{pH} 8,1 \mathrm{~mm}-\mathrm{HDTA})$ and centrifuged for $1 \mathrm{~h}$ in a Spinco SW41 rotor at $200000 \mathrm{~g}$ at $4^{\circ} \mathrm{C}$. Eleven fractions of approximately $1.2 \mathrm{ml}$ each were taken and $70 \mu \mathrm{l}$ of the first and last fractions, containing approximately $1 \mu \mathrm{g} \mathrm{DNA}$ each, were adjusted to $30 \mathrm{mM}-\mathrm{CaCl}_{2}$ in TEN buffer ( $20 \mathrm{~mm}$-Tris/HCl pH 8, $1 \mathrm{~mm}$-EDTA, $20 \mathrm{~mm}-\mathrm{NaCl}$ ). These were introduced independently into calcium-treated $E$. coli $\mathrm{C} 600 \mathrm{r}^{-} \mathrm{m}^{-}$cells as described by Cohen et al. (1972). Transformants were selected on MacConkey agar supplemented with $30 \mu \mathrm{g}$ kanamycin or ampicillin $\mathrm{ml}^{-1}$. Colonies were subsequently replicated to reciprocal plates.

Electron microscopy of DNA. The methods of Coetzee \& Pretorius (1979) involving benzyldimethylalkylammonium chloride (BAC) were used. Plasmid RP4 DNA (molecular mass 36 MDal; Jacob et al., 1977) was used as internal length standard for measurements of electron micrograph negatives which were rear-view projected. An Electronic Graphics calculator (Numonics Corp., Lansdale, Pa, U.S.A.) was used for measurements.

For demonstration of hairpin loop structures, plasmid $\left(150 \mu \mathrm{g} \mathrm{ml}^{-1}\right)$ was denatured in $1 \mathrm{mM}-\mathrm{Tris} / \mathrm{HCl}, \mathrm{pH} 8$, $13 \mathrm{mM}$-EDTA and $90 \%$ formamide at $60^{\circ} \mathrm{C}$ for $30 \mathrm{~min}$ and left on the bench for $30 \mathrm{~min}$. Formaldehyde was added to $2.5 \%$ and the mixture was kept on ice for $1 \mathrm{~h}$. A $10^{-2}$ dilution was made into droplet solution (100 mM-sodium acetate, $50 \mathrm{~mm}$-triethanolamine $\mathrm{pH} 8,30 \%(\mathrm{v} / \mathrm{v})$ formamide and $0.01 \%(\mathrm{w} / \mathrm{v}) \mathrm{BAC})$. Droplets of $50 \mu 1 \mathrm{were}$ formed and processed for electron microscopy according to Coetzee \& Pretorius (1979).

Temperature sensitivity. Plasmid-bearing strains $\left(10^{-5}\right.$ dilution of stationary phase stock) were grown overnight with aeration in nutrient broth (Oxoid, no. 2, CM67) at 25,37 and $43^{\circ} \mathrm{C}$, plated on non-selective MacConkey agar and grown at $37^{\circ} \mathrm{C}$. Colony counts were made and plates replicated to MacConkey agar containing either kanamycin or ampicillin at $30 \mu \mathrm{g} \mathrm{ml}^{-1}$. Replica colonies were scored.

Phage $t$ sensitivity. Phage t was spot tested (Bradley et al., 1981) at various concentrations $\left(10^{8}-10^{3}\right.$ p.f.u. $\left.\mathrm{ml}^{-1}\right)$ on lawns of bacteria carrying different plasmids.

DNAase production. Plasmid-bearing strains in exponential growth and a Staphylococcus aureus control strain were inoculated into DNAase test agar plates (Gibco Bio-cult Diagnostics), grown at $37^{\circ} \mathrm{C}$ and flooded with $1 \mathrm{M}$ $\mathrm{HCl}$. Clear zones revealed extracellular DNAase activity.

Transfer of $R$ factors. Methods were as described by Datta et al. (1971) and Datta \& Hedges (1971).

\section{RESULTS}

Identification of plasmids $R 394 a$ and $R 394 b$. Plasmid isolates from R394 carrying $E$. coli strains J53, J53-1 and J62-1 revealed the presence of two plasmids. Those from strain J62-1 were separated by sucrose gradient centrifugation and transformation as described above. Two colonies that were resistant only to kanamycin contained a single plasmid, R394a. Transformants that were resistant only to ampicillin (2000 colonies) contained another plasmid, named R394b. Neither plasmid coded for resistance to any other antibiotic. No heavy metal resistance was observed.

No extracellular DNAase was detected in cultures of $\mathrm{C} 600 \mathrm{r}^{-} \mathrm{m}^{-}$(R394a), whereas Matsumoto et al. (1978) observed DNAase activity in strains carrying the T group plasmid Rts1.

Temperature sensitivity. R394a and $\mathrm{R} 394 \mathrm{~b}$ were retained in $E$. coli $\mathrm{C} 600 \mathrm{r}^{-} \mathrm{m}^{-}$at growth temperatures of 25,37 and $43^{\circ} \mathrm{C}$, in agreement with Coetzee et al. (1972) with respect to R394 in $E$. coli $\mathrm{J} 53$. This is in contrast to the temperature sensitivity displayed by other plasmids of the IncT group (Coetzee et al., 1972).

Electron microscopy. Purified plasmid DNA of R394a and R394b, co-mounted with plasmid RP4 DNA, facilitated molecular mass determinations. These were $102 \pm 4 \mathrm{MDal}$ (9 molecules) for R394a and 11.0 $\pm 0.4 \mathrm{MDal}$ (15 molecules) for R394b.

Complete denaturation and limited renaturation of plasmid DNA revealed one hairpin loop structure in R394a, with dimensions of 800 and 900 base pairs for the stem and loop respectively. These are in agreement with those found by Pretorius \& Coetzee (1980). No such structure was observed in R394b. 
Conjugational transfer and incompatibility. R394a was transferred by conjugation between strains of $E$. coli $\mathrm{K} 12$, with an efficiency of about $10^{-4}$ per donor $\mathrm{h}^{-1}$. R394b was not transmissible from strains carrying this plasmid alone, but ampicillin resistance was efficiently mobilized by R394b from donors carrying both plasmids.

Conjugational transfer of $\mathrm{N} 3$ into $\mathrm{C} 600 \mathrm{r}^{-} \mathrm{m}^{-}(\mathrm{R} 394 \mathrm{~b})$ led to elimination of ampicillin

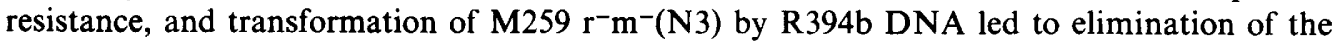
resident plasmid. Thus R394b is an N plasmid. Phage PR4 did not lyse C600 $\mathrm{r}^{-} \mathrm{m}^{-}(\mathrm{R} 394 \mathrm{~b})$, thus this plasmid is probably unable to produce $\mathrm{N}$ pili, consistent with the observation that it is transfer defective.

Conjugation of R401 into strains carrying R394a led to loss of kanamycin resistance and the reciprocal transfer induced loss of the markers of $\mathrm{R} 401$. Thus, R394a is a plasmid of group T. This finding was confirmed by the observation that phage $t$ plated upon $C 600 \mathrm{r}^{-} \mathrm{m}^{-}$(R394a) but not upon $\mathrm{C} 600 \mathrm{r}^{-} \mathrm{m}^{-}$(R394b).

Cointegrate formation and transposition. Strain J53, carrying R394a and R394b, was mated with J62(N3) (Table 1). Transfer of N3 led to the elimination of ampicillin resistance, but kanamycin resistance was retained. Hence, the two plasmids were maintained separately in this culture. Transfer of kanamycin resistance from J53(R394a)(R394b) to J62(N3) did not lead to co-transfer of ampicillin resistance or the loss of tetracycline resistance. Selection for transfer of ampicillin resistance to $\mathrm{J} 62(\mathrm{~N} 3)$ led to the elimination of tetracycline resistance from more than half of the recipients, but about $40 \%$ retained the markers of $\mathrm{N} 3$ (Table 1 , experiment 5) and these were stable during growth in drug-free medium.

The seven transcipients which stably carried resistance markers of all three plasmids were examined. One (Table 1, experiment 6) appeared to carry R394a and a plasmid coding for resistance to ampicillin and tetracycline. The latter was incompatible with $\mathrm{R} 15$ but not with $\mathrm{R} 394 \mathrm{a}$ (data not shown) and was therefore a plasmid of group N. It was presumably produced by recombination (perhaps transposition) between $\mathrm{R} 394 \mathrm{~b}$ and N3.

Table 1. Conjugations to test compatibility properties

\begin{tabular}{|c|c|c|c|c|c|}
\hline Experiment & Donor & Recipient & $\begin{array}{l}\text { Selective } \\
\text { antibiotic* }\end{array}$ & $\begin{array}{l}\text { Number of } \\
\text { transcipients } \\
\text { selected }\end{array}$ & $\begin{array}{l}\text { Non-selected } \\
\text { markers of } \\
\text { transcipients } \dagger\end{array}$ \\
\hline $1 \ddagger$ & J53(N3) & $\mathrm{C} 600 \mathrm{r}^{-} \mathrm{m}^{-}(\mathrm{R} 394 \mathrm{~b})$ & Tc & 16 & $\operatorname{Ap}^{s}(16)$ \\
\hline 2 & J53(R401) & $\mathrm{C} 600 \mathrm{r}^{-} \mathrm{m}^{-}(\mathrm{R} 394 \mathrm{a})$ & $\mathrm{Sm}$ & 8 & $\mathrm{Km}^{\mathrm{s}}(8)$ \\
\hline 3 & $\mathrm{C} 600 \mathrm{r}^{-} \mathrm{m}^{-}(\mathrm{R} 394 \mathrm{a})$ & J53(R401) & $\mathrm{Km}$ & 8 & $\mathrm{Sm}^{\mathrm{s}}(8)$ \\
\hline 4 & J62(N3) & J53(R394a)(R394b) & Tc & 15 & $\mathrm{Km}^{\mathrm{r}} A \mathrm{p}^{\mathrm{s}}(15)$ \\
\hline 5 & J53(R394a)(R394b) & J62(N3) & $\begin{array}{l}\mathrm{Km} \\
\mathrm{Ap}\end{array}$ & $\begin{array}{r}8 \\
31\end{array}$ & $\begin{array}{l}\operatorname{Tc}^{r} \mathrm{Ap}^{\mathrm{s}}(8) \\
\mathrm{Tc}^{\mathrm{s}} \mathrm{Km}^{\mathrm{s}}(3) ; \mathrm{Tc}^{\mathrm{s}} \mathrm{Km}^{\mathrm{r}}(15) \\
\mathrm{Tc}^{\mathrm{r}} \mathrm{Km}^{\mathrm{s}}(6) ; \mathrm{Tc}^{r} \mathrm{Km}^{\mathrm{r}}(7)\end{array}$ \\
\hline 6 & $\begin{array}{l}\text { One TcKmAp } \\
\text { transcipient of } \\
\text { conjugation } 5\end{array}$ & $\mathbf{J} 53$ & $\begin{array}{l}\mathrm{Km} \\
\mathrm{Ap} \\
\mathrm{Tc}\end{array}$ & $\begin{array}{l}12 \\
14 \\
10\end{array}$ & $\begin{array}{l}A p^{s} \mathrm{Tc}^{\mathrm{s}}(11) ; \mathrm{Ap}^{r} \mathrm{Tc}^{r}(1) \\
\mathrm{Km}^{\mathrm{s}} \mathrm{Tc}^{r}(14) \\
\mathrm{Ap}^{r} \mathrm{Km}^{\mathrm{s}}(10)\end{array}$ \\
\hline 7 & $\begin{array}{l}\text { A second } \mathrm{TcKmAp} \\
\text { transcipient of } \\
\text { conjugation } 5\end{array}$ & $\mathrm{~J} 53$ & $\begin{array}{l}\mathrm{Km} \\
\mathrm{Ap} \\
\mathrm{Tc}\end{array}$ & $\begin{array}{l}16 \\
16 \\
10\end{array}$ & $\begin{array}{l}A p^{r} T c^{s}(15) ; A p^{s} T c^{s}(1) \\
K m^{r} T c^{s}(14) ; \mathrm{Km}^{s} \operatorname{Tc}^{s}(2) \\
K m^{s} A p^{s}(10)\end{array}$ \\
\hline 8 & $\begin{array}{l}\text { ApKmTcs } \\
\text { transcipient of } \\
\text { conjugation } 7\end{array}$ & $\mathrm{~J} 62(\mathrm{~N} 3)$ & $\left\{\begin{array}{l}\mathrm{Ap} \\
\mathrm{Km}\end{array}\right.$ & $\begin{array}{l}16 \\
16\end{array}$ & $\begin{array}{l}\mathrm{Km}^{r} T \mathrm{c}^{\mathrm{s}}(16) \\
\mathrm{Ap}^{\mathrm{r}} \mathrm{T}^{\mathrm{s}}(14) ; \mathrm{Ap}^{r} \mathrm{~T} \mathrm{c}^{\mathrm{r}}(2)\end{array}$ \\
\hline 9 & $\mathrm{~J} 62(\mathrm{~N} 3)$ & $\begin{array}{l}\text { Donor strain used } \\
\text { in conjugation } 8\end{array}$ & Tc & 16 & $\mathrm{Ap}^{r} \mathrm{Km}^{\mathrm{r}}(16)$ \\
\hline
\end{tabular}

* Antibiotics were incorporated into minimal agar containing supplements permitting growth of the recipient but not the donor strain. Antibiotics: Tc, tetracycline; Sm, streptomycin; Km, kanamycin; Ap, ampicillin.

$\dagger$ Figures in parentheses show the number of strains of each resistance pattern.

$\$$ The reciprocal to this transfer, that of $\mathrm{R} 394 \mathrm{~b}$ to a host carrying N3, was effected by transformation and led to elimination of the resident plasmid in all of ten cases studied. 
The other six transcipients all behaved similarly to each other. On conjugation, two sorts of transcipients, Tc only or ApKm predominated (Table 1, experiment 7 gives typical results). The plasmid conferring resistance to tetracycline seems to be $\mathrm{N} 3$ unaltered, but the other two resistances appear to be conferred by a single plasmid. We interpret this as a cointegrate structure, since (Table 1, experiments 8 and 9) it is able to eliminate N3 but is not itself eliminable by entry of this plasmid.

\section{DISCUSSION}

Results indicate that plasmid R394 (Coetzee et al., 1972) consists of two plasmids, R394a and R394b. The original interpretation of R394 was that this was a single plasmid with anomalous properties ascribed to a phenomenon termed 'dislodgement' (Coetzee et al., 1972). We have shown that R394 consists of two separate plasmids each with a single resistance determinant, that are capable of forming cointegrate structures corresponding perhaps to transposition intermediates (Gill et al., 1978). Pairs of plasmids which can exist either as separately replicating structures or as cointegrates may explain many of the anomalous results described as dislodgement. In its independent state a plasmid may be eliminated by an incompatible $\mathbf{R}$ factor that would be unable to effect the elimination of the cointegrate. Hence, the results of incompatibility testing will depend upon the state of the plasmids in the clone selected for testing and this may vary on different occasions.

The hairpin loop structure observed on R394a was first detected (Pretorius \& Coetzee, 1980) on the genome of $P$. mirabilis phage 5006M HFT $k$ (Coetzee, 1974). This phage is a derivative of high frequency transducing phage $5006 \mathrm{M}$ and originated from transduction of R394 to $P$. mirabilis strain PM5006 (Coetzee, 1974). The kanamycin resistance marker on the phage 5006M HFT $k$ genome may be located on the hairpin loop structure (Pretorius \& Coetzee, 1980) and the present observation is consistent with this. A similar structure was not evident on R394b, supporting the observation than the ampicillin resistance marker on the genome of phage 5006M HFT $a k$ is not located in a hairpin loop structure (Pretorius \& Coetzee, 1980). The latter phage, a derivative of phage $5006 \mathrm{M} \mathrm{HFT} k$, was obtained by transduction of the ampicillin resistance marker of R394 (Coetzee, 1975).

\section{REFERENCES}

BECK, Y. \& COETZEE, J. N. (1980). Mobilization of the Proteus morganii chromosome by $\mathrm{R}$ plasmids. Journal of General Microbiology 118, 539-542.

Bradley, D. E., Coetzee, J. N., Bothma, T. \& Hedges, R. W. (1981). Phage $t$ : a group T plasmiddependent bacteriophage. Journal of General Microbiology 126, 397-403.

Clowes, R. C. \& HAYES, W. (1968). Experiments in Microbial Genetics. Oxford and Edinburgh: Blackwell Scientific Publications.

CoetzeE, J. N. (1974). High frequency transduction of kanamycin resistance in Proteus mirabilis. Journal of General Microbiology 84, 285-296.

CoetzeE, J. N. (1975a). High frequency transduction of resistance to ampicillin and kanamycin in Proteus mirabilis. Journal of General Microbiology 87, 173176.

Coetzee, J. N. (1975b). Specialized transduction of kanamycin resistance in a Providence strain. Journal of General Microbiology 88, 307-316.

Coetzee, J. N. (1979). Genetic circularity of the Proteus mirabilis linkage map. Journal of General Microbiology 110, 171-176.

Coetzee, J. N. \& Krizsanovich-Williams, K. (1976). Transduction of leucine auxotrophs of Proteus mirabilis to prototrophy or antibiotic resistance by $P$. mirabilis high frequency transducing bacteriophages. Journal of General Microbiology 92, 369-374.

Coetzee, W. F. \& Pretorius, G. H. J. (1979). Factors which influence the electron microscopic appearance of DNA when benzyldimethylalkylammonium chloride is used. Journal of Ultrastructure Research 67, 33-39.

Coetzee, J. N., Datta, N. \& Hedges, R. W. (1972). R factors from Proteus rettgeri. Journal of General Microbiology 72, 543-552.

Coetzee, J. N., Datta, N., Hedges, R. W. \& ApPelbaum, P. C. (1973). Transduction of R factors in Proteus mirabilis and P. rettgeri. Journal of General Microbiology 76, 355-368.

Cohen, S. N., Chang, A. C. Y. \& Hsu, L. (1972). Non chromosomal antibiotic resistance in bacteria: Genetic transformation of Escherichi coli by R-factor DNA. Proceedings of the National Academy of Sciences of the United States of America 69, 21102114.

Datta, N. \& Hedges, R. W. (1971). Compatibility groups among $f^{-} \mathbf{R}$ factors. Nature, London 234, 222-223.

Datta, N., Hedges, R. W., Shaw, E. J., Sykes, R. B. 
\& Richmond, M. H. (1971). Properties of an R factor from Pseudomonas aeruginosa. Journal of Bacteriology 108, 1244-1249.

Gill, R., Hefrron, F., Dougan, G. \& Falkow, S. (1978). Analysis of sequences transposed by complementation of two classes of transposition deficient mutants of Tn3. Journal of Bacteriology 136, 742-756.

Hedges, R. W., Datta, N., Kontomichalou, P. \& SMITH, J. T. (1974). Molecular specificities of $R$ factor-determined beta-lactamases: Correlation with plasmid compatibility. Journal of Bacteriology 117, 56-62.

Jacob, A. E., Shapiro, J. A., Yamamoto, L., Smith, D. I., Cohen, S. N. \& Berg, D. (1977). Plasmids studied in Escherichia coli and other enteric bacteria. In DNA Insertion Elements, Plasmids, and Episomes, pp. 607-638. Edited by A. I. Bukhari, J. A. Shapiro \& S. L. Adhya. New York: Cold Spring Harbor Laboratory.

Matsumoto, H., Kamio, Y., KobaYashi, R. \&
TerawaKi, Y. (1978). R plasmid Rtsl-mediated production of extracellular deoxyribonuclease in Escherichia coli. Journal of Bacteriology 133, 387-389.

Matthew, M. \& HeDGeS, R. W. (1976). Analytical isoelectric focusing of $\mathbf{R}$ factor-determined $\beta$-lactamases: correlation with plasmid compatibility. Journal of Bacteriology 125, 713-718.

Prakash, R. K., SChilperoort, R. A. \& Nuti, M. P. (1981). Large plasmids of fast growing Rhizobia: homology studies and location of structural nitrogen fixation (nif) genes. Journal of Bacteriology 145, 1129-1136.

Pretorius, G. H. J. \& Coetzee, W. F. (1980). Proteus mirabilis phages $5006 \mathrm{M}, 5006 \mathrm{MHFT} k$ and $5006 \mathrm{MHFT} a k$ : physical comparison of genome characteristics. Journal of General Virology 49, 33-39. Stanisich, V. A. (1974). The properties and host range of male-specific bacteriophages of Pseudomonas aeruginosa. Journal of General Microbiology 84, 332342. 